\title{
Socio-economic Status of Fishers of Ratnagiri, Maharashtra
}

\author{
B. M. Yadav*, S. V. Patil, S. S. Mandavkar, S. M. Wasave, \\ M. M. Shirdhankar, K. J. Chaudhari and B. V. Naik \\ College of Fisheries (Dr. B. S. Konkan Agriculture University), Ratnagiri, Maharashtra, India \\ *Corresponding author
}

\section{A B S T R A C T}

\begin{tabular}{|l||}
\hline K e y w o r d s \\
$\begin{array}{l}\text { Socio-economic, } \\
\text { fishers, Ratnagiri, } \\
\text { Maharashtra }\end{array}$ \\
\hline Article Info \\
\hline $\begin{array}{l}\text { Accepted: } \\
\text { 20 August } 2020 \\
\text { Available Online: } \\
\text { 10 September } 2020\end{array}$ \\
\hline
\end{tabular}

Socio-economic condition of the fishers in Maharashtra is very low. The present study study was carried out to assess socio-economic status of fishers of Ratnagiri, Maharashtra. Information was collected through the well-structured interview schedule. A total of 64 fishermen were selected randomly for interview. The study revealed that $82.8 \%$ fishermen were male and all are involved in fish and fishing related activity. Mostly middle age fishers (36-50 years) were involved in fishing activity. Majority $(82.8 \%)$ respondents were married and were lived in joint family. It was found that $71.9 \%$ families has the only one earner. Almost 95\% fishers were educated and live in pacca house $(90.6 \%$ ). Around 98.4 $\%$ fishermen had bank account. Maximum number of families daily household expenditure was up to Rs.300/-.Fishers must be encouraged to attend different training programmes to improve their skills in their respective works and it would help them to gain more income. Fishers must also be motivated to take alternative livelihoods.

\section{Introduction}

Asia is the world's largest continent constituting $60 \%$ of the world's population. Within Asia, India is one of the largest and most populous country in the world having most diversified livelihood occupations. Most of the people in the country depend on agriculture and its allied sectors including fisheries for their livelihood. Fishing is the oldest and most important livelihood option for the inhabitants of the coastal area of the country from time immemorial. This natural resource along with the marine environment provides livelihood opportunities for the coastal people. Fisheries sector is playing very important role in the socio-economic development of the fishermen community (Jonwal and Deshmukh, 2017). Apart from socio-economic development, fisheries also serve as the valuable and cheap source of protein of the country (Prabhavathi and Krishna, 2017) and important source of foreign exchange. Marine fisheries sector is dominated by the socio-economically backward artisanal and small scale fishers whose lives are closely intertwined with the oceans and seas (National Fisheries Policy, 2020). Socioeconomic status of fishermen mostly depends on fisheries resources. It is estimated that more than 12 million people are directly engaged in fishing activities and 
about 60 million are exclusively depend on fisheries activities for livelihood in India (Rao et al., 2016). Fishery plays an important role in Indian economy, but the economic conditions of the fishermen are very poor (Nayak and Mishra, 2008). Fishermen are separated into a different community and they are one of the backward communities in India. They spend their whole life in poverty due to uncertain prospects of income (Nandi \& Parmanik, 1994). The fishermen are very important communities, they live hand to mouth and considered as the poorest among the poor (Kabir et al., 2013). Socioeconomic conditions of the fishers in India are very low (Bijayalakshmi and Ngangbam, 2014).

Socio-economic status (SES) is a measure of an individual's or family's economic and social position in relation to others, based on various variables responsible for that like income, education, occupation, family effluence, physical assets, social position, social participation, caste, muscle power, political influence, etc. (Reza et al., 2015). Due to lack of knowledge among fishers and fishing communities, leads to poor planning and implementation of various fisheries management programs (Devi et al., 2012b and Devi et al., 2014). It is essential to study the baseline information to initiate proper developmental steps and improve the socioeconomic and livelihood of fishermen. Considering this the present study has been undertaken with the objective to studysocioeconomic status of fisher community.

\section{Materials and Methods}

\section{Selection of study area}

The present survey was carried out in Kasarveli, Kalbadevi and Warwade village (Map 1) of Ratnagiri district, Maharashtra as these are important fishing villages in Ratnagiri district. Majority of the villagers belongs to fishermen community and involved in fishing related work.

\section{Selection of respondent}

The respondents were fishermen who were involved in fishing as primary as well as secondary income source for their livelihood. In present study, the information was randomly collected from the 64fishermen comprising fishing boat crew member, fresh/dry fish seller, fish boat owner.

\section{Sampling}

To study the socioeconomic status of the fishermen the interview schedule (Fig. 1) and Google forms (Survey administration app) was made and distributed to the fishermen of selected villages of Ratnagiri district engaged in fishing activities. For calculation of percentage, frequency statistical tool like MSExcel was used.

\section{Results and Discussion}

In the fisheries, socio-economic status of fishers plays a key role in various productive activities. Socio-economic parameters such as socio-personal information, economic information and enterprise information were studied.

\section{Social status of fishers}

Social status of fishers is presented in Table 1.

\section{Gender}

The study revealed that majority of fishers $(82.8 \%)$ were male while $17.2 \%$ were females. Raghavan et al., 2016 in their study in Jafna Province reported that males comprised a higher percentage $(54.4 \%)$ than the females $(45.6 \%)$. However, females (12 $\%)$ were involved in marketing and 
processing of the caught fish. Bhuyan and Islam (2016) reported that involvement of men and women in fishing was $86 \%$ and $14 \%$ respectively in Bangladesh.

\section{Age}

Higher percentages of fishers $(56.25 \%)$ were in middle age group (36-50 years) followed by old age group (above 51years) fishers (26.56\%), while $17.19 \%$ fishers were in young age group (up to 35 years). Immanuel (2004) in her study in Kerala revealed that 52.67 percent of the fishermen belonged to middle age group followed by old age group $(27.33 \%)$ and young age group (20.00\%). Charles et al., 2009 in their study reported that 52.78 percent of the fishermen belonged to middle age group followed by 40.28 percent in old age group and 6.9 percent in the young age group. Ujjain and Patel (2011) in their study in Danti village, Valsad district (Gujarat), India observed that $24.7 \%$ fishermen in 18-36 age group, 57.0\% fishermen in 37-54 age group and 18.3\% fishermen in 55-72 age group. Devi et al., (2012) studied socioeconomic and cultural profile fishers around the Loktak lake of Manipur and had reported that $44 \%$ of the fishermen were more than 46 years old belonging to the old age group.

\section{Marital status}

As far as marital status of fishermen is concerned, it was found that majority of the fishers $(82.8 \%)$ were married while, $14.1 \%$ was unmarried and $3.1 \%$ was widow. Dr.Jayaselvi (2016) studied an economic and health status of fishermen in Tiruchendur and reported that out of total respondents $86 \%$ of them got married and $14 \%$ of them were unmarried. Nayak and Mishra (2008) their study in Ganjam district, Orissa reported that out of the total population 16,976 are unmarried whereas 19,504 are married and
1,235 are widow.

\section{Religion}

In this study it was observed that the peoples of three villages involved in fishing occupation were $100 \%$ Hindu. Pandey and Mishra (2001) in their study on economic feasibility of fish culture in the Faizabad district, U.P, India reported that cent percent fishermen of this district are Hindus. Chavan et al., 2009 studied socio economic analysis of fishermen in Maharashtra, India and reported about $86 \%$ of the fisher folk families were Hindus. Ulman et al., (2008) studied traditional fishing practices and scio-cultural activities of koli community in konkan region of India and reported that majority (95\%) of the fishermen in fishing business were Hindu.

\section{Family type}

The result showed that $62.5 \%$ fishermen families were live in joint family while $37.5 \%$ families were live in nuclear family. Bhargavi et al., 2020 carried out study on socioeconomic status of fisher women community in Vizianagaram district of Andhra Pradesh, India and found that the majority of the respondents lived in nuclear families $(64.9 \%)$ whereas remaining $35.1 \%$ lived in joint families.

Ujjain and Patel (2011) in their study on Socio-economic Status of fishermen community of Danti village in Valsad district (Gujarat) India observed that $78.0 \%$ of fishermen belong to nuclear family and 22.0 $\%$ of fishermen belong to joint family. Kabir et al., (2012) studied livelihood status of fishermen of the old Brahmaputra river, Bangladesh and reported that $60 \%$ fishermen families were jointed and $40 \%$ of families were nuclear. Ali et al., (2010) studied the livelihood status of the fish farmers in some selected areas of Tarakanda upazila of 
Mymensingh distric and reported that $42.5 \%$ family of the fish farmers were joint family and $57.5 \%$ family were nuclear family.

\section{Family size}

In current investigation family size of the fishermen was divided into two categories on the basis of the number of family members ie. small family (five or less than five members) and big family (more than five members). The result revealed that around $75 \%$ families were small (five or less than five peoples), $25 \%$ families were big (more than five peoples in family). Bhargavi et al., 2020 in their study in Andhra Pradesh, India and reported $48.7 \%$ of the respondents had a family size of $<5$ family members and $51.3 \%$ constituted with $>5$ family members. Anon (2005) studied socio-economic status of fishermen in Nuvvulrevu village of Srikakulam district, Andhra Pradesh and found that $38 \%$ of the families consisted of $<5$ members and $62 \%$ families were with $>5$ members.

Dheeraj kumar et al., (2018) studies on fisheries status and socio-economic conditions of fisher community in Dholi region, Muzaffarpur, Bihar, India and found that maximum fishers $(37.50 \%)$ belongs to medium family composed of 5 to 6 members, followed by large family which is composed of 7 or more members $(43.75 \%)$. The least number is of small family i.e., composed of 2 to 4 members $(18.75 \%)$.

\section{Number of household earner}

The result showed that maximum number $(71.9 \%)$ of fishers has only one earner in their family followed by $18.8 \%$ families with two earners and $9.4 \%$ with three earners in family. Santhosh et al., 2015 studied on socioeconomics of fishermen community around the Junglighat fish landing centre, South
Andaman and reported that that $89.36 \%$ of the families were dependent on 1-2 members for earnings. These findings are more or less similar to the present study.

\section{Occupational status}

In present study it was observed that fifty percent villagers are fisher, $35.9 \%$ was fishing vessel crew members followed by $12.5 \%$ was fresh-dry fish seller/fish dryers and 1.6\% peoples were involved in other business. Vichare (2010) had reported that only 17 percent respondents from mechanized boat owners in Versova were found to be the owner cum worker fishers and in Satpati this number was found to be quite high (57\%).

Further she had reported that majority of the mechanised boat owners $(70$ percent in Versova and 60 percent in Satpati) claimed that they do not have any secondary occupation though in reality some of them found to have the same.

Dheerai kumar et al., (2018) studies on fisheries status and socio-economic conditions of fisher community in Dholi region, Muzaffarpur, Bihar, India and reported $34.44 \%$ people of village are only concern towards fishing practice either capture or culture, about $20.66 \%$ of people were working as vegetable seller including fishing practices.

Fishing and agriculture practice is done by $29.50 \%$ people of this region and remaining $15.50 \%$ people of this region were fisher as well as working as labour. Raghavan et al., (2016) reported that Main occupation of (90\%) fisher families was fishing, majority of the fishermen were doing fishing throughout the year and rest being part-time fishermen, they were engaged in fishing and labour work. 
Table.1 Socio-personal status of fishers of Ratnagiri, Maharashtra (N=64)

\begin{tabular}{|c|c|c|c|}
\hline No. & Characters & Category & Percentage \\
\hline \multirow[t]{2}{*}{1} & \multirow[t]{2}{*}{ Gender } & Male & 82.80 \\
\hline & & Female & 17.20 \\
\hline \multirow[t]{3}{*}{2} & \multirow[t]{3}{*}{ Age } & Young age (Upto 35) & 17.19 \\
\hline & & Middle age (36-50) & 56.25 \\
\hline & & Old age (Above 51) & 26.56 \\
\hline \multirow[t]{3}{*}{3} & \multirow[t]{3}{*}{ Marital status } & Married & 82.8 \\
\hline & & Unmarried & 14.1 \\
\hline & & Widow & 3.1 \\
\hline 4 & Religion & Hindu & 100 \\
\hline \multirow[t]{2}{*}{5} & \multirow[t]{2}{*}{ Family type } & Joint & 62.5 \\
\hline & & Nuclear & 37.5 \\
\hline \multirow[t]{2}{*}{6} & \multirow[t]{2}{*}{ Family size } & Small (Five or less than five members) & 75 \\
\hline & & Big (More than five members in family) & 25 \\
\hline \multirow[t]{3}{*}{7} & \multirow{3}{*}{$\begin{array}{l}\text { Number of household } \\
\text { earners }\end{array}$} & One earner & 71.9 \\
\hline & & Two earners & 18.8 \\
\hline & & Three earners & 9.4 \\
\hline \multirow[t]{4}{*}{8} & \multirow[t]{4}{*}{ Occupation status } & Fisher & 50 \\
\hline & & Fishing vessel crew members & 35.9 \\
\hline & & Fresh-dry fish sellers/fish dryers & 12.5 \\
\hline & & Other business & 1.6 \\
\hline \multirow[t]{6}{*}{9} & \multirow[t]{6}{*}{ Educational status } & Illiterate & 4.7 \\
\hline & & Primary & 31.3 \\
\hline & & Secondary & 50 \\
\hline & & Higher secondary & 4.7 \\
\hline & & Graduate & 6.3 \\
\hline & & ITI & 3.1 \\
\hline \multirow[t]{2}{*}{10} & \multirow[t]{2}{*}{ House type } & Pacca house & 90.6 \\
\hline & & Kaccha house & 9.4 \\
\hline \multirow[t]{3}{*}{11} & \multirow[t]{3}{*}{ Type of ration card } & Yellow & 26.6 \\
\hline & & Orange & 71.9 \\
\hline & & White & 1.6 \\
\hline \multirow[t]{2}{*}{12} & \multirow[b]{2}{*}{$\begin{array}{l}\text { Would you like to } \\
\text { continue fishing as } \\
\text { primary/secondary } \\
\text { occupation in your } \\
\text { next generation? }\end{array}$} & Yes & 42.6 \\
\hline & & No & 57.4 \\
\hline
\end{tabular}


Table.2 Enterprise details of fishers of Ratnagiri, Maharashtra $(\mathrm{N}=64)$

\begin{tabular}{|c|c|c|c|}
\hline No. & Enterprise details & Category & Percentage \\
\hline 1. & Type of fishing & Capture & 100 \\
\hline 2. & Fishing vessel & Mechanize & 100 \\
\hline \multirow[t]{2}{*}{3.} & \multirow[t]{2}{*}{ No of fishing vessel } & 1 no. & 92.9 \\
\hline & & 2 no. & 7.1 \\
\hline \multirow[t]{3}{*}{4.} & \multirow[t]{3}{*}{ Fishing gear } & Gill net & 21.4 \\
\hline & & Purseine net & 3.6 \\
\hline & & Trawel net & 75 \\
\hline
\end{tabular}

Table.3 Economical status of fishers of Ratnagiri, Maharashtra (N=64)

\begin{tabular}{|c|l|c|c|}
\hline No. & \multicolumn{1}{|c|}{ Characters } & Category & Percentage \\
\hline 1. & Account in bank & Yes & 8.4 \\
\hline \multirow{2}{*}{ 2. } & \multirow{2}{*}{ Source of finance for business } & No & 1.6 \\
\hline \multirow{2}{*}{} & & Own savings & 81.3 \\
\hline \multirow{2}{*}{ 3. } & \multirow{2}{*}{ Loan for fishing } & Money from fish suppliers & 12.5 \\
\hline \multirow{2}{*}{ 4. } & \multirow{2}{*}{ Daily house hold expenditure } & Bank & 4.7 \\
\hline & & Yes & 1.6 \\
\hline & & No & 16 \\
\hline & & Up to Rs.300/-, & 84 \\
\hline
\end{tabular}

Fig.1 Interview with fishermen
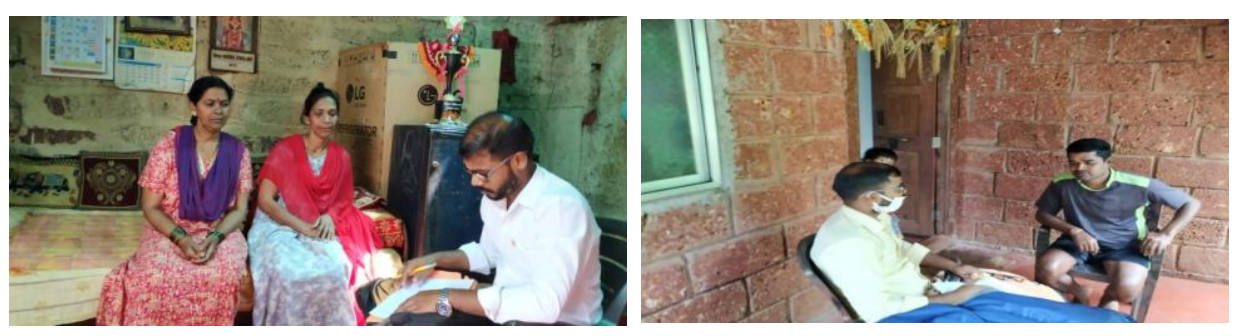

Map.1 Showing study villages of Ratnagiri, Maharashtra

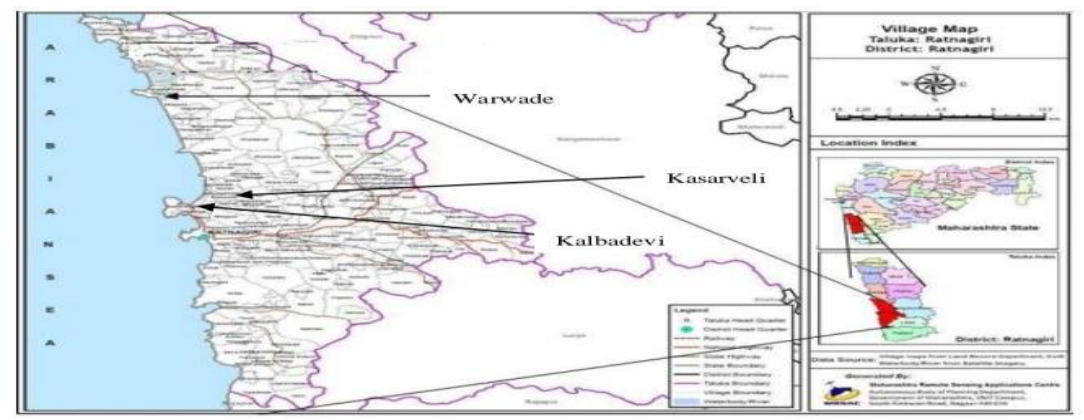




\section{Educational status}

Study revealed that $50 \%$ fishers were educated upto secondary level followed by $31.3 \%$ with primary education. Around $4.7 \%$ fishermen were Illiterate as well as educated upto higher secondary level, $6.3 \%$ fishers were graduate and $3.1 \%$ with ITI education. Ujjain and Patel (2011) in their study on socio-economic status of fishermen community of Danti village in Valsad district, Gujarat reported that majority $(90.0 \%)$ of fishermen had primary and HSC level followed by $10.0 \%$ fishermen were illiterate, while no one having higher education. Chavan et al., 2009 in their study in Maharashtra reported that $30 \%$ of the fisher possessed primary level education, $31 \%$ with secondary level education, $7 \%$ with secondary level of education while $32 \%$ fishers are not educated. Ali et al., 2010 in their study on livelihood status of the fish farmers in some selected areas of Tarakanda upazila of Mymensingh district reported that about 10\% of farmers had no education, $37.5 \%$ farmers completed their primary education, $17.5 \%$ with SSC, $25 \%$ with HSC level and 7.5\% with bachelor degree.

\section{House type}

House type of fishermen was divided into two categories ie. pacca house made of red bricks or RCC structure and Kaccha house made up of soil walls. The result revealed that majority $(90.6 \%)$ of fishermen have pacca house while $9.4 \%$ live in kaccha house. Chavan et al., 2009 in their study in Maharashtra reported that $92 \%$ of the houses, where marine fisher families live were found to be pucca houses and in Sindhudurg district almost all the houses are pucca houses. Alam et al., (2009) reported that $82.22 \%$ of housing structures were katcha while $11.11 \%$ were semi-pucca and only $6.66 \%$ were pucca.

\section{Type of ration card}

In the study area ration card was divided into four categories such as yellow, orange, white no ration card. The results obtained in present investigation revealed that majority $(71.9 \%)$ of fishermen were having orange ration card, $26.6 \%$ fishers were with yellow ration card and $1.6 \%$ fishermen with white ration card. Santhosh et al., 2015 reported that $87.1 \%$ of the families were under APL category and $12.9 \%$ of the families were under BPL category. These findings are more or less similar to the present study.

\section{Would you like to continue fishing as primary/secondary occupation for your next generation?}

In this study a unique question was asked "whether you like to continue fishing as primary/secondary occupation for your next generation?". The study reported that around $57.4 \%$ fishermen say no and $42.6 \%$ fishermen say yes to continue this present occupation to next generation. Reason behind not to handover their occupation to next generation may be due to less catch of fish, less profit, high business operation cost and high risk at sea.

\section{Enterprise details of fishers}

Enterprise details of fishers are presented in Table 2.

\section{Type of fishing}

In study area cent percent fishermen were involved in capture fisheries opertaion for their livelihood.

\section{Fishing vessel}

Study revealed that the fishers of studied area were involved in the capture fishery and they 
all have mechanize fishing vessel. Ujjain and Patel (2011) in their study on socio-economic status of fishermen community of Danti village in Valsad district, Gujarat reported that $17.3 \%$ of fishermen were having local boat, $13.0 \%$ were having semi mechanized boat and $69.7 \%$ were having mechanized boat for fishing activity. These findings are more or less similar to the present study.

\section{Number of fishing vessel}

In current study it was observed that the $92.9 \%$ fishers were having only one fishing vessel while $7.1 \%$ fishermen were having two fishing vessels. Hossain et al., 2014 in their study in Chittagong district, Bangladesh reported that few fishermen had their own boats, some purchased boat through group ownership and rests were taken from moneylenders through dadon.

\section{Fishing gear}

In present investigation it was found that $21.4 \%$ fishermen were having gill net, $3.6 \%$ were with purseseine net while majority (75\%) were using trawl net for fishing. Ulman et al., 2008 studied in Konkan region, Maharashtra reported that in Ratnagiri and Raigad mainly dol net and trawl net used for fishing.

\section{Economical status of fishers}

Economical status of fishers of Rtanagiri was studied and same is is presented in Table 3.

\section{Account in bank}

It was observed that majority $(98.4 \%)$ of fishermen from studied villages have the bank account while only $1.6 \%$ fishermen donnot having bank account. Dhande et al., 2017 carried out study on socio-economic status of fishers of coastal India and reported that among all the coastal states and UTs, almost 83.67 percent fishers have savings account either in bank or post office.

\section{Source of finance for business}

As far as source of finance for business is concerned, it was observed that majority $(81.3 \% \%)$ of fisher were using their own savings for fishing activity, $12.5 \%$ fishermen burrow money from fish suppliers, $4.7 \%$ fishermen take help of finance company and $1.6 \%$ fishermen approach to banks. Ali et al., 2010 in their study on livelihood status of the fish farmers in some selected areas of Tarakanda upazila of Mymensingh district reported that $90 \%$ of the fish farmers used their own money for fish farming, while remaining $10 \%$ of the farmers received loan from friends, bank and NGOs.

\section{Loan for fishing}

Form this study it was observed that $84 \%$ fishermen not availing loan for fishing activity and $16 \%$ were availing loan for their fishing activity. Bhuyan and Islam (2016) studied socio-economic conditions of the fishing community in Bangladesh and reported that during the odd situation, they overcome the financial crisis by taking loan from somiti (45\%), some of them take loan from NGO (12\%) and relatives (10\%). Hossain et al., 2014 reported that most of the fishermen had taken money for investment through dadon (64\%) and only $36 \%$ fishermen invested their own money for purchasing boats and nets. Reza et al., 2015 in their study reported that that $64 \%$ of the fishermen received credit (loan) from different NGO's while $36 \%$ of the fishermen used their own credit.

\section{Daily household expenditure}

Study revealed that $46.9 \%$ families daily house hold expenditure was up to Rs.300/-, 
$43.8 \%$ families daily house hold expenditure was between Rs. 300 to 500/- and 9.4\% families have the more than Rs. 500/- daily house hold expenditure.

In conclusion the fishing is the major economic activity in studied villages. Around $95 \%$ fishers were literate but the number of fishers who have studied higher secondary and above education was found to be less. The fishers should be encouraged towards higher education as it forms the base for the development. The cent percent peoples are involved in to fishing as their main occupation. Fishers must be encouraged to attend different training programmes to improve their skills in their respective works and it would help them to gain more income. Fishers must also be motivated to take alternative livelihoods. A proper extension linkage mechanism should be developed for effective transfer of technologies.

\section{Acknowledgements}

Authors would like to acknowledge the finanacial support from Indian Council of Social Science Research (ICSSR), Ministry of HRD, Government of India, New Delhi and Vice-Chancellor, Dr. Balasaheb Sawant Konkan Agricultural University, Dapoli.

\section{References}

Alam, M.S., Flowra, F.A., Salam, M.A., Kabir, A.K.M.A. and Ali, H. (2009). Fishing gears, fish marketing and livelihood status of the poor fishermen around the Basantapurbeel at Lalpur Upazila. J. Agrofor. Environ. 3(1):173177.

Ali, H., Azad, M.A.K., Anisuzzaman, M., Chowdhury, M.M.R., Hoque, M. and Shariful, M.I. (2010). Livelihood status of the fish farmers in some selected areas of Tarakandaupazila of
Mymensingh district. J. Agrofor. Environ. 3(2): 85-89.

Anon, (2005). Report on the socio-economic analysis of Nuvvulrevu village in Srikakulam district of Andhra Pradesh, Central Marine Fisheries Research Institute, Visakhapatnam.

Bhargavi, K., Chirwatkar, B.B., Das, A., Behera, S. and Bhakta, D. (2020).Socioeconomic status of fisherwomen community in coastal Vizianagaram district of Andhra Pradesh. India. J.Fish. 8 (1):741-745.

Bhuyan, S. and Islam, S. (2016). Present status of socio-economic conditions of the fishing community of the Meghnariver adjacent to Narsingdi district, Bangladesh. J. Fish. Livest. Prod. 4(4): 1-5.

Bijayalakshmi, D. and Ngangbam, A. (2014). Socioeconomic conditions and cultural profile of the fishers in India. J. Agri. Vet. Sci. (IOSRJAVS), 7(9): 42-48.

Charles, J., Vasanthakumar, J., Balasubramanium, S. and Geethalakshmi, V. (2009). Technology development efficiency and sociopersonal characteristics of researchers in marine fisheries. Fish. Technol. 46(2):182-192.

Chavan, B.R., Yakupitiyage, A. and Kumar, S. (2009). Socio-economic analysis of fishermen at coastal fishery management in Maharashtra, India. Asia. Pac. J. Rural. Dev. 19(2):31-45.

Devi, N.B.L., Ngangbam, A.K., Dr. Sheela, I. andAnanthan, P.S. (2012). Study of fishers socioeconomic and cultural profile around the Loktak lake of Manipur, India. J.Agri.Vet.Sci. 1(5):4856.

Devi, N.B.L., Ngangbam,. A.K. and Sheela, I. (2012b). A study on existing fisheries management system and the problems faced by the fishers in Loktaklake of Manipur. J.Agri.Vet.Sci.1(5):22-28. 
Devi, N.B.L., Ngangbam, A.K. and Biswal, N.N. (2014). A review on the current fisheries management system in Manipur with special reference to Loktaklake. J.Agri.Vet.Sci.7(4):63-66.

Dheeraj, K., Mehta, R. Yadav, R., Shivam, K. and Manoranjan, K. (2018).Studies on fisheries status and socio-economic conditions of fisher community in Dholi region, Muzaffarpur, Bihar, India.J. Entomol. Zool. Stud. 6(3): 76-80.

Dhande, K.K., Ramasubramanian, V., Krishnan, M., Ananthan, P.S., Vinay, A. and Ravi, K.S.M. (2017). Socioeconomic status of fishers of coastal India. Int.J.Curr.Microbiol.Appl.Sci., 6(9): 2267-2280.

Jayaselvi, S, (2016). An economic and health status of fishermen in Tiruchendur.ShanlaxInt.J.Arts.Sci.Hum. 4(1):35-53.

Hossain, S., Hasan, M.T., Alam, M.T. and Mazumder, S.K. (2014).Socioeconomic condition of the fishermen in Jelepara under Pahartoli of Chittagong district.J.Sylhet. Agri.Univ.1(1):65-72.

Immanuel, S. (2004).Linkage among research, extension and clientele systems in marine fisheries in Kerala, Unpub. M.Sc. (Agri) thesis, Annamalai University, Tamilnadu.

Jonwal, N.R. and Deshmukh, D.R. (2017) Socio -economic status of fishermen community of Paithan area. Trends. Fish. Res. 6(3): 2319-4758.

Kabir, K.M.R., Adhikary, R.K., Hossain, M.B. and Minar, M.H. (2012). Livelihood status of fishermen of the old Brahmaputra river, Bangladesh. World. Appl. Sci. J.16 (6): 869-873.

Kabir, K.M.R., Adhikary, R.K., Hossain, M.B. and Minar, M.H. (2013) Livelihood status of fishermen of the old Brahmaputra river, Bangladesh. World. Appl. Sci. J. 16(6):869-873.

Nandi, N.C. and Parmanik, S.K. (1994).Crab and crab fisheries of Sunderban. Hindustan Publishing Corporation, Delhi.130-143.

National Fisheries Policy, (2020). http://nfdb.gov.in/PDF/National_Fisheri es_Policy_2020.

Nayak, L. and Mishra, A. (2008). Socioeconomic condition of fishermen and its effect one environment: a case study of Ganjam district, Orissa. Nat.Environ.Pollut.Technol@Techno. Sci. Pub. 7 (1):111-11

Pandey, A.C. and Mishra, J.P. (2001).Economic feasibility of fish culture in the district Faizabad (U.P), India a case study. In: Encyclopaedia of agricultural marketing. (Naurang Rai for Mittal Publications, New Delhi) 817099-740-2 (7):263-270.

Prabhavathi, K. and Krishna, P. (2017). Socio-economic conditions of fishermen community in some selected areas of Nizampatnam area, Guntur district, Andhra Pradesh, India. Int. j. zool. stud.2(5): 212-215.

Rao, G.S., Sathianandan, T.V., Kuriakose, S., Mini, K.G., Najmudeen, T.M., Jayasankar, J. and Mathew, W.T. (2016). Demographic and socioeconomic changes in the coastal fishing community of India. Indian J.Fish.63(4): 1-9.

Raghavan, N., Sivashanthini, K. and Sutharshiny, S. (2016). Socio-economic status of fishers in Allaipiddy village, Jaffna.Vingnanam.J.Sci.12(1\&2):42-48.

Reza, S., Hossain, S., Hossain, U. and Zafar, A. (2015).Socio-economic and livelihood status of fishermen around the Atrai and Kankra rivers of Chirirbandar Upazila under Dinajpur district. Int. J. Fish. Aquat. Stud. 2(6): 402-408.

Santhosh, R.B., Kumar, R.R., Malakar, B. and Venu, S. (2015).Socio-economics of fishermen community around the 
Junglighat fish landing centre, South Andaman - a case study. Res. J. Biol. Sci. 5(7): 1860-1867.

Ujjania, N.C. and Patel, A.N. (2011). Socioeconomic status of fishermen community of Danti village in Valsad district (Gujarat) India. Emerg. Trends.Dev.Res.18(1-2):25-30.

Ulman, Y.N., Naik, V.G. and Talathi, J.M.
(2008).Traditional fishing practices and scio-cultural activities of Koli community in Konkan region of India. Asian.Agri. Hist.J.12(4): 311-319.

Vichare, P.S. (2010).A study on effect of migration on livelihood of coastal fishers in Maharashtra. Unpub. M.F.Sc (thesis), Central Institute of Fisheries Education, Mumbai.

\section{How to cite this article:}

Yadav, B. M., S. V. Patil, S. S. Mandavkar, S. M. Wasave, M. M. Shirdhankar, K. J. Chaudhari and Naik, B. V. 2020. Socio-economic Status of Fishers of Ratnagiri, Maharashtra. Int.J.Curr.Microbiol.App.Sci. 9(09): 3011-3021. doi: https://doi.org/10.20546/ijcmas.2020.909.372 